\title{
Color Development in Maleic Anhydride Copolymers
}

\section{Color Development with a Basic Agent}

By Toshio Chiba* and Teruhiko Yonezawa*

Maleic Anhydride copolymers undergo a rapid coloring (absorption maximum at about $555 \mathrm{~m} \mu$ in methanol) on addition of some basic agents. It has been found that the coloring was coursed of elimination of carboxylic acid in the vinyl ester copolymers and of dehydrochlori. nation in the vinyl chloride copolymers, with formation of conjugated $\mathrm{C}=\mathrm{C}$ double bonds in the polymer molecules. The colored polymers have almost the same absorption maximum irrespective of the kind of copolymer and base. Consequently, it seems that the coloring of the polymers is due to the conjugated double bonds of $\mathrm{C}=\mathrm{C}$ and $\mathrm{C}=\mathrm{O}$, and not to the conjugated polyene structures.

* Fuji Photo Film Co. Research Laboratory (Minami-ashigara-machi, Kanagawa)

訂 正

著者より左記のごとく訂正がありましたのでお知らせし訂正いたします。

\begin{tabular}{|c|c|c|c|c|c|c|}
\hline 著者名 & 巻 & 号 & ページ & 㯗 - 行 & 綡 & 正 \\
\hline $\begin{array}{l}\text { 山田正盛 } \\
\text { 高瀨 }\end{array}$ & 18 & 189 & 88 & 左欄, 3 行 & 徐々に見出される & 徐々に乱される \\
\hline 同 & 同 & 同 & 同 & Table 4 最下段 & Dimethylmaleate & Diethylmaleate \\
\hline 石田慎一 & 同 & 191 & 189 & 右, 4. 考察より 12 行目 & ‥と反応し，エチレンを発生し… & ‥と反応し, エタンを発生し, \\
\hline 荒井定吉 & 同 & 193 & 304 & 欧文要旨の上から 3 行目 & ...cylindrical, elastoviscometer... & ...cylindrical elastoviscometer... \\
\hline 同 & 同 & 同 & 同 & 同上から 9 行目 & ...is expected to the... & ...is expected to be the... \\
\hline 同 & 同 & 同 & 同 & 同下から 4 行目 & $\ldots C^{\prime}(\omega)=G\left(\dot{\gamma}_{e q}\right)$ & $\ldots G^{\prime}(\omega)=G\left(\dot{\gamma}_{e q}\right)$ \\
\hline 同 & 同 & 同 & 同 & 下から 2 行目 & date & data \\
\hline
\end{tabular}

